\title{
ПРИКЛАДНА МЕХАНІКА
}

РОМАНЮК О.Д., к.т.н., доцент ТЕЛІПКО Л.П., К.Т.Н., доценТ

Дніпровський державний технічний університет, м. Кам'янське

\section{ЗАГАЛЬНІ МЕТОДИ ОПТИМІЗАЦІЇ КІНЕМАТИЧНИХ ТА ДИНАМІЧНИХ ПАРАМЕТРІВ МАШИННОГО АГРЕГАТУ}

Вступ. У сталому режимі роботи кінематичні та динамічні характеристики машинного агрегату є періодичними функціями, оскільки має місце періодичний характер зміни діючих сил і передаточної функції механізму приводу. Тому задача пошуку методів оптимізації характеристики машинного агрегату є актуальною. Зазвичай у роботах ставиться задача зменшення амплітуди коливання швидкості ланки зведення за допомогою збільшення зведеного моменту інерції, тобто збільшенням інерційності механізму, шляхом встановлення на валу ланки зведення додаткової маси, яку називають маховиком [1, 2, 3].

Використання маховика дає можливість суттєво знизити амплітуду коливань швидкості ланки зведення, так як спричиняє збільшення зведеного моменту інерції механізму. Проте даний підхід для вирішення поставленої задачі обумовлює наявність додаткової маси, що збільшує вагу механізму і відповідно його інерційність.

Для усунення відповідних недоліків додаткових махових мас необхідно в процесі попереднього проектування приводу виконавчого органу машинного агрегату підбирати такий стандартний редуктор, маховий момент обертальних вузлів якого відповідав би додатковій маховій масі. Практично підібрати відповідний стандартний редуктор неможливо, тому, доцільніше проектувати нові передаточні механізми, моменти інерції обертальних мас яких могли б виконувати функцію маховика $[4,5,6,7,8]$.

Використовуючи відповідний принцип проектування $[4,5,6,7,8]$ можна розв'язати поставлену задачу в першому наближені. Проте доцільніше поширити даний принцип на машинний агрегат в цілому, а не тільки на механічну передачу.

Постановка задачі. На сучасному етапі єдиним можливим шляхом наукового пошуку розв'язання задач оптимізації в механіці є метод математичного моделювання. Отримане розв'язання дає певне уявлення про взаємозв'язки елементів машини, яка проектується чи механізму, а також дозволяє цілеспрямовано змінювати параметри, а при необхідності і конструкцію механізму. За даними моделювання можна перевірити поведінку механізму в ідеальних та екстремальних умовах його роботи.

При моделюванні доцільно змінювати такі конструктивні параметри механізму, як розміри ланок, маси, передаточне відношення, амплітуду коливань, аналізуючи ступінь їх впливу на характеристики роботи машинного агрегату, виділяючи при цьому елементи, що мають найбільший вплив.

Поставлену задачу аналізу загальних методів оптимізації кінематичних та динамічних параметрів машинного агрегату розглянемо на математичній моделі, побудованій на основі принципу зведення мас та сил.

Згідно принципу зведення мас та сил, закон руху ланки зведення обумовлює періодична змінна зведеного моменту інерції механізму. Якщо характер зміни зовнішніх сил, що діє на ланки механізму, змінити практично неможливо, то при проектуванні машинного агрегату можна забезпечити оптимальний характер зміни зведеного момен- 
ту інерції, що обумовлює суттєве зменшення зміни швидкості обраної ланки зведення. Характер зміни зведеного моменту інерції $\Delta J_{3}$ за час усталеного руху може бути обраний таким, щоб відповідати змінам сумарної роботи. Якщо зміни кінетичної енергії $\Delta T$ механізму за рахунок зведеного моменту інерції дорівнюють змінам сумарної роботи $\sum A$, а саме

$$
\Delta T=\frac{1}{2} \Delta J_{3} \omega^{2}=\sum A,
$$

то обрана швидкість руху ланки зведення $\omega$ буде постійною. Це дасть можливість розв'язувати задачі оптимізації кінематичних та динамічних параметрів машинного агрегата в цілому.

У даному випадку сумарна робота розраховується згідно рівняння

$$
\sum A=A_{P} \pm A_{G} \pm A_{I}-A_{T}-A_{K . O .}
$$

де $A_{P}$ - робота рушійних сил, Дж; $A_{G}$ - робота сил ваги, Дж; $A_{I}$ - робота сил інерції, Дж; $A_{T}$ - робота сил тертя, Дж; $A_{K . O}$ - робота сил корисного опору, Дж.

Результати роботи. Базова математична модель машинного агрегата для вирішення поставленої задачі аналізу загальних методів оптимізації кінематичних та динамічних параметрів представлена на рис.1.

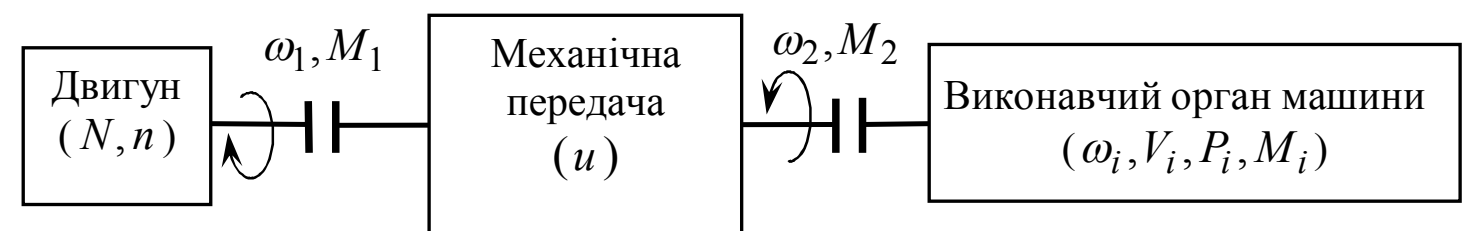

Рисунок 1 - Базова математична модель машинного агрегату

Елементами даної моделі є двигун, механічна передача та виконавчий орган машини, які характеризуються наступними параметри: $N$ - потужність двигуна, $B m ; n-$ швидкохідність двигуна $1 / x в л ; ~ u-$ передаточне число (відношення) механічної передачі; $\omega_{i}$ - кутова швидкість $i$ - тої ланки, $1 / c ; V_{i}$ - лінійна швидкість $i$-тої ланки, $\mu / c$; $P_{i}$ - сила яка діє на $i$ - ту ланку, $H ; M_{i}-$ момент сили $i-$ тої ланки, $H \times м$. Дані характеристики є внутрішніми параметрами відповідних елементів системи. До зовнішніх параметрів елементів моделі відносяться: $\omega_{1}$ - кутова швидкість вала двигуна, $1 / c$; $M_{1}$ - момент сил опору на валу двигуна, $H \times M$; $\omega_{2}-$ кутова швидкість вихідного вала механічної передачі, $1 / c ; M_{2}-$ момент сил опору на валу механічної передачі, $H \times$ м. Зовнішні параметри елементів моделі являються як вихідними, так і вхідними параметрами відповідних елементів.

3 метою оптимізації кінематичних та силових параметрів машинного агрегата на основі базової математичної моделі (рис.1) розглянемо можливі варіанти моделювання з використанням принципу зведення мас та сил. Таким чином, отримуємо три варіанти динамічних моделей в залежності від ланки зведення.

За ланку зведення вибираємо головний вал виконавчого органу машини рис.2. Відповідно кутова швидкість ланки зведення повинна дорівнювати кутовій швидкості головного вала виконавчого органу машини

$$
\omega \equiv \omega_{2}
$$




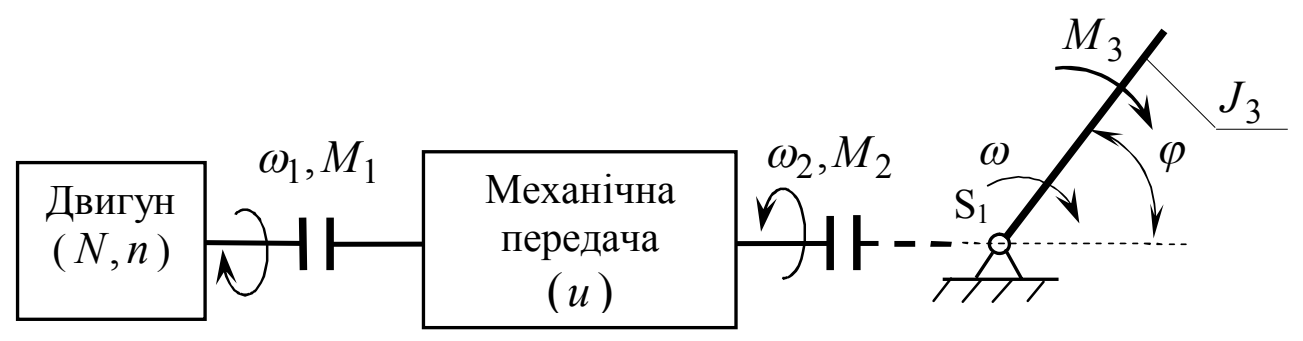

Рисунок 2 - Динамічна модель виконавчого органу машини

У даній моделі величина зведеного моменту інерції визначається рівнянням

$$
J_{3}=\sum_{i=1}^{n} J_{S i}\left(\frac{\omega_{i}}{\omega}\right)^{2}+\sum_{i=1}^{n} m_{i}\left(\frac{V_{S i}}{\omega}\right)^{2}
$$

де $n$ - кількість рухомих ланок в механізмі; $J_{S i}$ - момент інерції $i$-тої ланки механізму відносно осі яка проходить через центр маси ланки і перпендикулярна площині їі

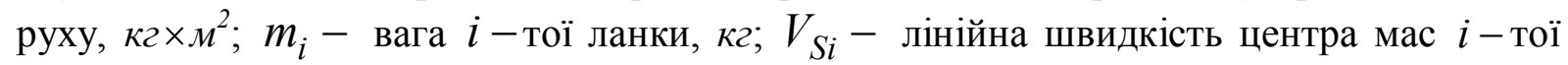
ланки, $M / c$.

Зведений момент всіх сил опору відповідно рівнянням

$$
M_{3}=\sum_{i=1}^{n} P_{i} \frac{V_{i}}{\omega} \cos \alpha_{i}+\sum_{i=1}^{n} M_{i} \frac{\omega_{i}}{\omega},
$$

де $\cos \alpha_{i}-$ косинус кута між силою та швидкістю $i$-тої ланки.

Дана динамічна модель забезпечує можливість змінювати величину моментів інерції відповідних ланок виконавчого органа машини в процесі його проектування, шляхом зміни зведеного моменту інерції, величина якого повинна дорівнювати відповідній маховій масі.

За ланку зведення вибираємо швидкохідний вал передаточного механізму, рис.3. Відповідно кутова швидкість ланки зведення повинна дорівнювати кутовій швидкості швидкохідного вала передаточного механізму

$$
\omega \equiv \omega_{1}
$$

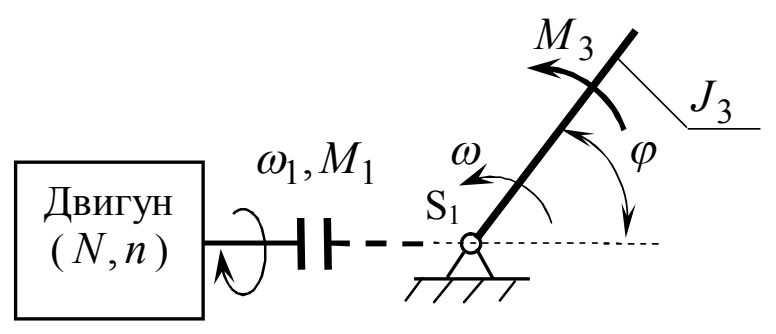

Рисунок 3 - Динамічна модель механічної передачі 


\section{Прикладна механіка}

У даній моделі величина зведеного моменту інерції визначається рівнянням

$$
J_{3}=\sum_{j=1}^{k} J_{j}+\sum_{i=1}^{n} J_{S i}\left(\frac{\omega_{i}}{\omega}\right)^{2}+\sum_{i=1}^{n} m_{i}\left(\frac{V_{S i}}{\omega}\right)^{2},
$$

де $k$ - кількість обертальних вузлів у механічній передачі; $J_{j}-$ момент інерції обертальних вузлів механічної передачі, $к 2 \times M^{2}$.

Зведений момент сил опору відповідно рівнянню

$$
M_{3}=\sum_{j=1}^{k} M_{j}+\sum_{i=1}^{n} P_{i} \frac{V_{i}}{\omega} \cos \alpha_{i}+\sum_{i=1}^{n} M_{i} \frac{\omega_{i}}{\omega},
$$

де $M_{j}-$ момент сил опору на відповідних валах передаточного механізму $H \times M$.

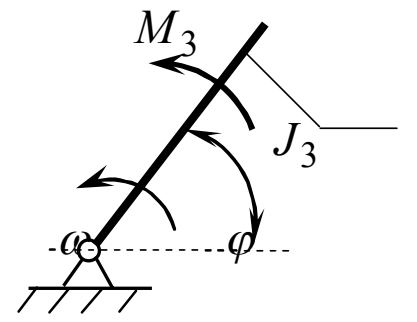

Рисунок 4 - Динамічна модель машинного агрегата

Відповідна динамічна модель забезпечує можливість змінювати величину моментів інерції обертальних вузлів механічної передачі в процесі проектуванні $[4,5,6,7,8]$. Даний підхід забезпечує можливість зміни зведеного моменту інерції, залишаючи незмінними параметри виконавчого органу машини. Роль маховика в даному випадку виконують махові маси обертальних вузлів механічної передачі.

За ланку зведення вибираємо вал двигуна, рис.4. Відповідно кутова швидкість ланки зведення повинна дорівнювати кутовій швидкості вала двигуна

$$
\omega \equiv \omega_{1}
$$

Згідно даній моделі величина зведеного моменту інерції визначається рівнянням

$$
J_{3}=J_{1}+\sum_{j=1}^{k} J_{j}+\sum_{i=1}^{n} J_{S i}\left(\frac{\omega_{i}}{\omega}\right)^{2}+\sum_{i=1}^{n} m_{i}\left(\frac{V_{S i}}{\omega}\right)^{2},
$$

де $J_{1}-$ момент інерції ротора електродвигуна, $к 2 \times M^{2}$, оскільки дані двигуни найбільш поширені на практиці.

Зведений момент сил опору відповідно рівнянню

$$
M_{3}=M_{1}+\sum_{j=1}^{k} M_{j}+\sum_{i=1}^{n} P_{i} \frac{V_{i}}{\omega} \cos \alpha_{i}+\sum_{i=1}^{n} M_{i} \frac{\omega_{i}}{\omega},
$$

де $M_{1}-$ момент сили на валу електродвигуна, $H \times M$.

Дана модель являється більш універсальною для розв'язування різноманітних задач оптимізації кінематичних та силових параметрів машинного агрегата.

Використовуючи дану модель, можна вирішувати задачі оптимізації передаточної функції машинного агрегата $[9,10]$, оптимізувати час розгону машинного агрегата [10], а також розв'язувати задачу в комплексі, на етапі попереднього проектування. Це дасть можливість підбору відповідних мас ланок складальних одиниць, моменти інерції 
яких відповідають маховому моменту маховика, що забезпечить необхідну стабілізацію кінематичних та динамічних характеристик машинного агрегата.

Висновки. На підставі розглянутого аналізу можна зробити висновок, що найбільш оптимальним розв'язанням задач оптимізації кінематичних та динамічних параметрів машинного агрегата $є$ комплексний підхід, який полягає в проектуванні не схеми приводу, а машинного агрегата в цілому, тобто, використовуючи тільки стандартний електродвигун, а виконавчий орган машини бажано проектувати разом з механізмом привода. Такий підхід забезпечує оптимальне розв'язання практично любої задачі, яку ставить перед інженерами та конструкторами сучасне виробництво.

Метод компонування схеми приводу машинного агрегата із стандартних механізмів можна вважати застарілим та економічно не вигідним, оскільки він обумовлює підвищення габаритних розмірів, надлишкову масу, нерівномірний термін довговічності та рівень надійності відповідних елементів системи.

\section{ЛІТЕРАТУРА}

1. Геминтерн В.Н., Коган Б.М. Методы оптимального проектирования: М.: Энергия, 1980. $160 \mathrm{c}$.

2. Соболь И.М., Статников Р.Б. Выбор оптимальных параметров в задачах со многими критериями: М.: Дрофа, 2006, 175 с.

3. Джента Дж. Накопители кинетической енергии. Теория и практика современных маховичных систем: М.: Мир, 1988, 430 с.

4. Романюк О.Д. Вибір махових мас ланок передаточних механізмів на основі оптимізації передаточної функції. Математичне моделювання. 2015. №2(33). С. 52-54.

5. Романюк О.Д. Оптимізація мас зубчастих коліс механічної передачі на етапі попереднього проектування. Математичне моделювання. 2017. №2(35). С. 37-40.

6. Романюк О.Д. Основні підходи оптимізації мас зубчастих коліс механічної передачі. Математичне моделювання. 2018. №1(38). С. 118-123.

7. Romaniuk O.D. Mathematical models development of the mechanical transmission units. Математичне моделювання. 2019. №2(41). С. 53-61.

8. Романюк О.Д. Оптимізація мас валів і підшипників механічної передачі. Математичне моделювання. 2020. №1(42). С. 41-47.

9. Романюк О.Д., Теліпко Л.П. Оптимізація передаточної функції механічної передачі 3 метою підвищення точності роботи машинного агрегату. Збірник наукових праць Дніпровського державного технічного університету (технічні науки). 2019. №34. т. 1. С. 34-38.

10. Дослідження динаміки, міцності і технологічності механічних систем: монографія /Л.М. Мамаєв та ін. Кам’янське, 2017. 183 с. 